\title{
Relationship between land use and groundwater quality in six districts in the eastern region of Ghana
}

\author{
J. R. Fianko • S. Osae • D. Adomako • D. G. Achel
}

Received: 29 August 2007 / Accepted: 14 April 2008 / Published online: 12 July 2008

(C) The Author(s) 2008

\begin{abstract}
The chemical quality of groundwater in six district of the eastern region beneath the different types of land use areas of Ghana was examined to evaluate the effects of human activities on groundwater. Analyses indicate that groundwater in the studied area is fresh and generally suitable for most uses. The groundwater is generally characterised by a chemical facies of $\mathrm{Ca}-\mathrm{HCO}_{3}{ }^{-}, \mathrm{Na}-\mathrm{Cl}$ and mixed $\mathrm{Na}-\mathrm{Ca}-\mathrm{HCO}_{3}$ types and is weakly mineralised. Anthropogenic disturbances have had and continue to have an impact on the aquatic ecosystem of Ghana. High concentration of $\mathrm{Cl}^{-}$and TDS were found in wells in high residential areas while the highest levels of $\mathrm{Na}, \mathrm{Ca}$, $\mathrm{SO}_{4}{ }^{2-}$ and $\mathrm{NO}_{3}{ }^{-}$were found in agricultural and high density residential areas. About $50 \%$ of boreholes sampled have elevated level of $\mathrm{NO}_{3}{ }^{-}-\mathrm{N}$ emanating from agricultural runoff.
\end{abstract}

Keywords Aquifer. Groundwater quality · Nitrate · Pollution · Anthropogenic activities.

\footnotetext{
J. R. Fianko $(\varangle) \cdot$ S. Osae $\cdot$ D. G. Achel

Department of Chemistry, National Nuclear Research Institute, Ghana Atomic Energy Commission, P.O. Box LG 80, Legon-Accra, Ghana

e-mail: jrfianko@yahoo.com

D. Adomako

Department of Physics, National Nuclear Research

Institute, Ghana Atomic Energy Commission,

P.O. Box LG 80, Legon-Accra, Ghana
}

\section{Background}

The development of industrial and agricultural activities followed by the development of general social welfare has led during recent decades to an increase in the demand for potable water. This has also led to the production of great quantity of pollutants, with a serious risk of conservation of surface and groundwater quality.

The groundwater in the eastern region of Ghana have special economic significance, representing the country's greatest hydrostructure with freshwater. Groundwater in the eastern region of Ghana especially Akwapim North and South districts, East and West Akim Districts, Suhum-Kraboa-Coaltar Districts and the New Juaben Districts runs a high risk of pollution with agrochemicals, municipal and domestic waste because of the high density of urbanization and intense agricultural activities. Rivers across these districts are another source of pollution. In these situations, pollutants released on the ground surface may rapidly reach the aquifer and travel long distance in a very short time through preferential pathways, (Tazioli et al. 1995). Anthropogenic loading of nitrogen and phosphorous from industrial, municipal and agricultural sources has increased nutrient load in the aquifers.

The river basin within which the aquifers for these district lies have been identified by Water Resources Commission of Ghana as most problematic and vulnerable catchment on the priority list of issues especially on water pollution. Enhanced use of pesticides and fertilizers, improper land use, water shortage, urbanization and lack of adequate data and information for effective management were some of the problems identified, 
(Water Resources Commission 2003, Amuzu 1975). Intensive use of land and water involving complex structures built in watersheds necessitates the development of special approaches for studying and forecasting the effect of mans activities on the natural runoff regime.

Increasing water needs, constraints imposed by quality of different uses and the growing importance of contamination as a result of urban, industrial and agricultural activities makes it more necessary to consider aquifers as components of water resources system to increase dependable water supplies and to preserve water quality. The data collected is therefore aimed at evaluating the effects of human activities on groundwater and characterizing the chemical quality of water.

\section{The study area}

The Densu River basin is located in Southern Ghana and covers the South-Eastern part of the Greater Accra Region and the South-Western portion of the eastern region. The Densu River Basin lies between latitude $5^{\circ}$ $30^{\prime} \mathrm{N}-6^{\circ} 20^{\prime} \mathrm{N}$ and longitude $0^{\circ} 10^{\prime} \mathrm{W}-0^{\circ} 35^{\prime} \mathrm{W}$. The basin shares its catchment boundary with the Odaw and Volta basins to the east and north respectively, the Birim basin in the northwest and the Ayensu and Okrudu in the west. (Fig. 1). The climate of the basin is characterised by prevailing high temperatures and marked variations in the duration, intensity and seasonal distribution of rainfall. Temperatures are uniformly high throughout the year. The mean annual temperature is about $27^{\circ} \mathrm{C}$, with March/April being the hottest $\left(32^{\circ} \mathrm{C}\right)$ and August being the coolest month $\left(23^{\circ} \mathrm{C}\right)$.

The basin falls under two distinct climatic zones; the dry equatorial climate of the SE coastal plains, and the wet semi-equatorial climate further north from the coast. Both climatic zones are characterised by two rainfall regimes with different intensities (Dickson and Benneh 1980). The major rainy season extends from April/May to July and attains a peak in June when the maritime instability causes a surge of the moist south-westerly air stream resulting in the intensification of the monsoon rain. The annual rainfall ranges from $1,700 \mathrm{~mm}$ in the wet interior to $800 \mathrm{~mm}$ in the dry equatorial zone near the coast. A complex of Precambrian granite and granodiorite with associated gneiss underlie the larger part of the basin (about $90 \%$ ). The other formations are rocks of the Upper Birimian that occur at the watershed of the river in the northwest, and rocks of the Togo series, which underlie the southeast part of the basin and the area south

Fig. 1 Map of the study area

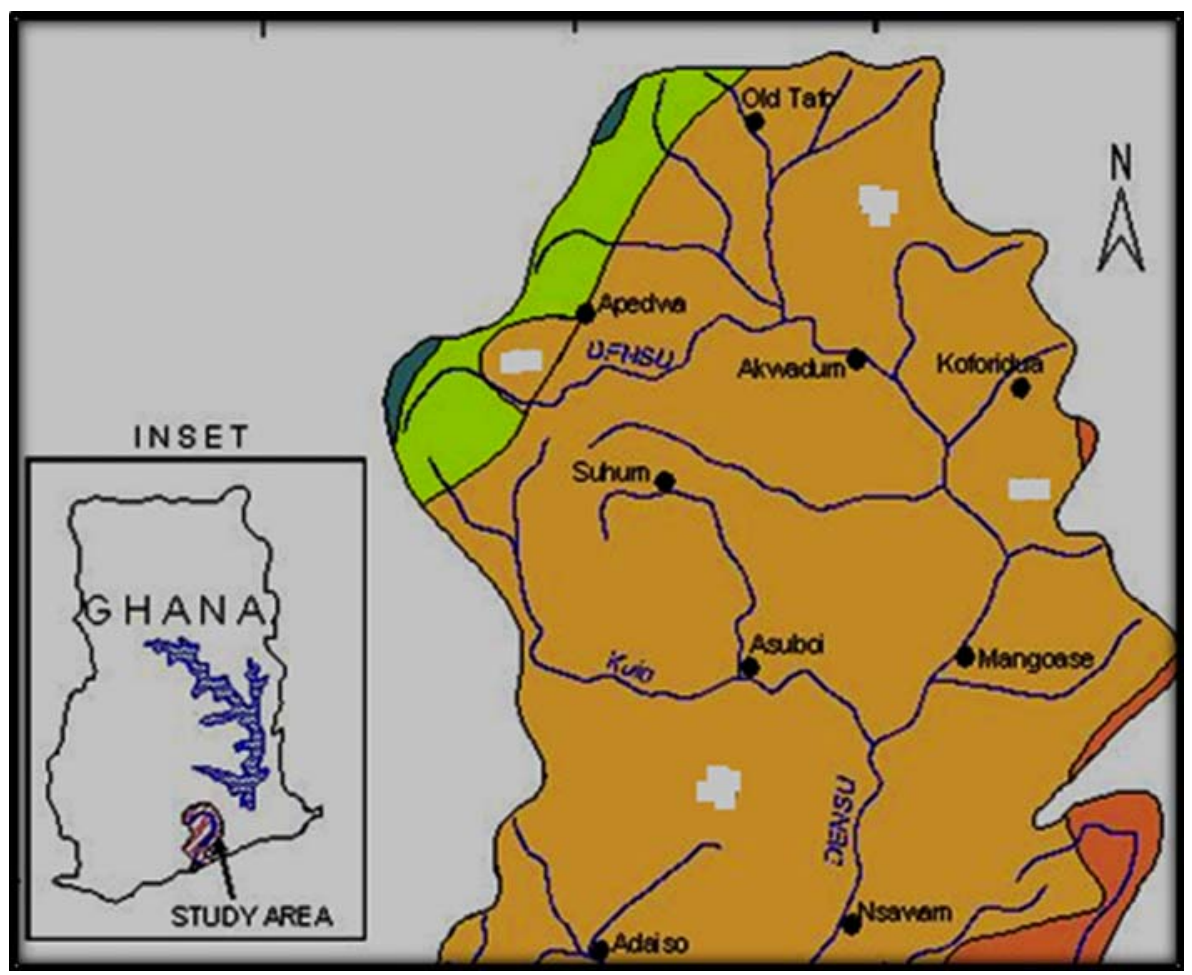




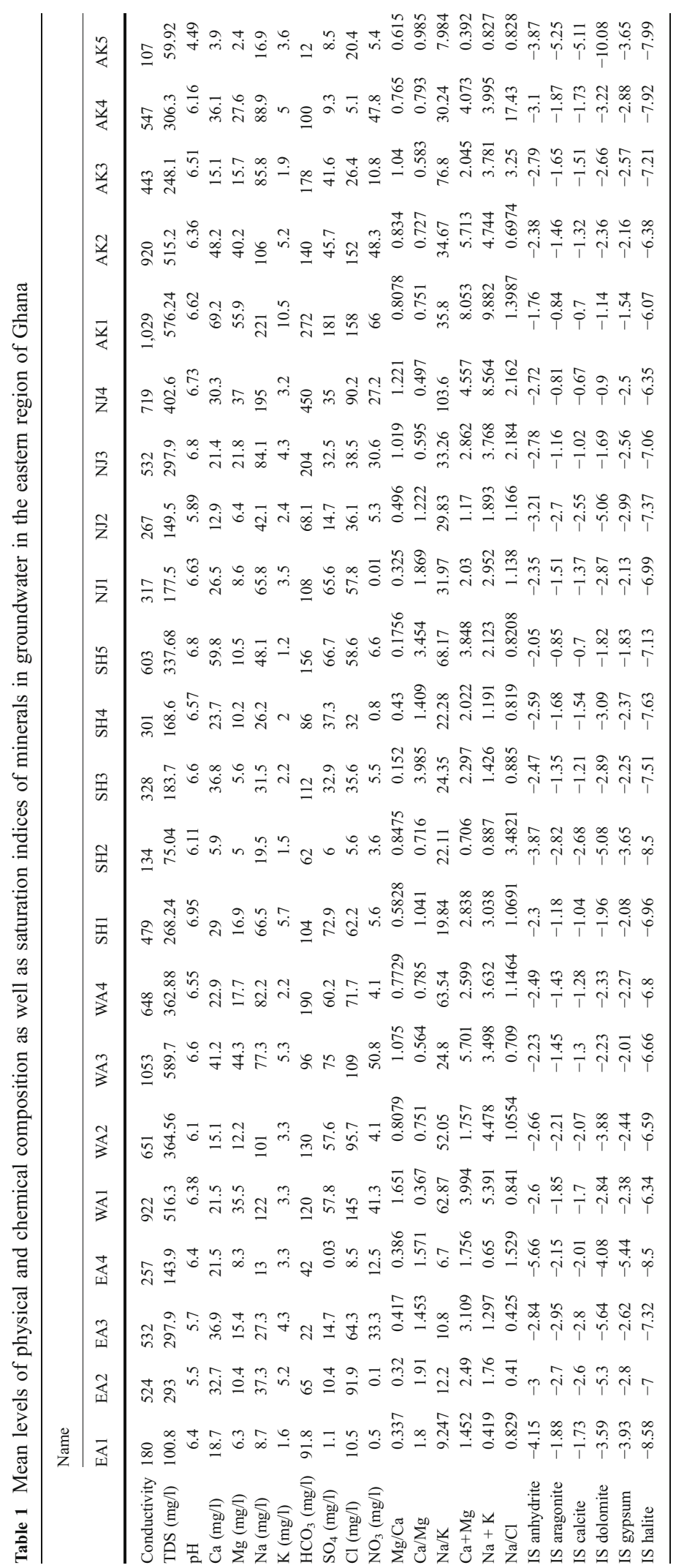


Fig. 2 Levels of $\mathrm{NO}_{3}{ }^{-}-\mathrm{N}$ in groundwater samples

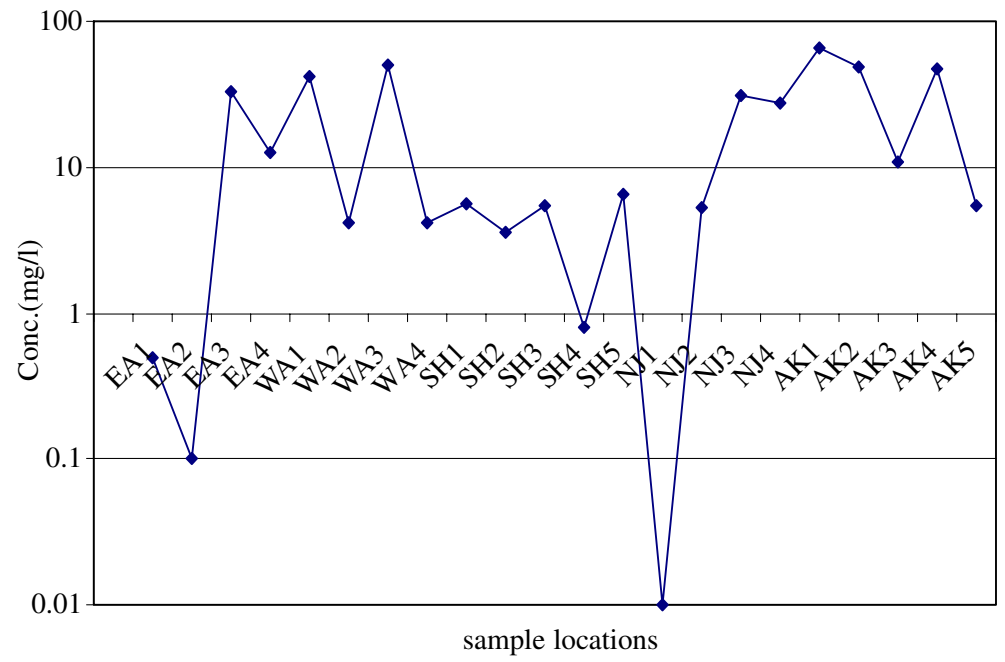

of Weija to the estuary. The Upper Birimian rocks consist mainly of metamorphosed lava and tuff, and pyroclastic rocks (Junner 1940). The rocks of the Togo Series are highly folded and jointed, and form the chain of hills known as the Akwapim-Togo Ranges, which extend from the coast near Accra to the Togo border. The rocks include sandstone, quartzite and quartz schist, shale, phyllite and some talc mica schist.

\section{Methodology}

Field and laboratory methods

Groundwater samples were individually collected from domestic and municipal wells into acid cleaned high density 11 polyethylene sampling bottles and analyzed independently. In all 18 boreholes and four hand dug wells were selected and sampled based on population density, level of activity in the area and importance of the facility to the community. The sampling groundwaters were from Akwapim (AK), East Akim (EA), West Akim (WA), Suhum (SH) and New Juaben (NJ) districts. Water samples from domestic and municipal wells were pumped out using existing infrastructure for over 20 min before samples were taken. Electrical conductivity, $\mathrm{pH}$ and temperature were measured using digital meters, portable Hach Conductivity meter, Metrolin model 691-pH meter and mercury-in-glass thermometer respectively immediately after sampling. Samples for major, minor and trace metal analysis were filtered through
Fig. 3 Sequence on ions in groundwater samples

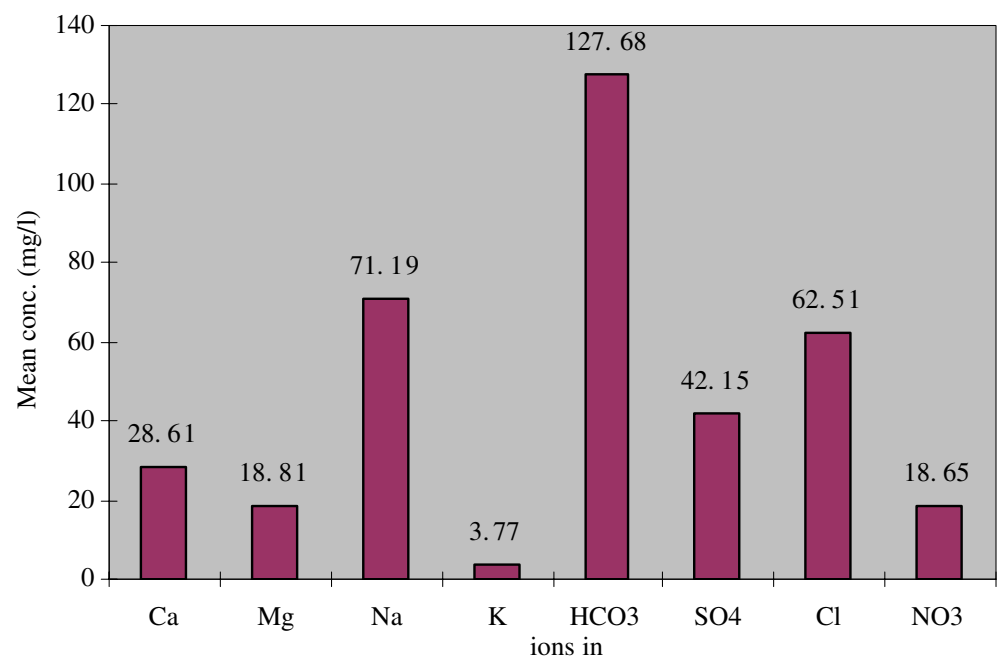


Fig. 4 Scattergram of $\mathrm{Cl}^{-}$ and $\mathrm{SO}_{4}{ }^{2-}$ ion concentrations in groundwater as a function of the electrical conductivity

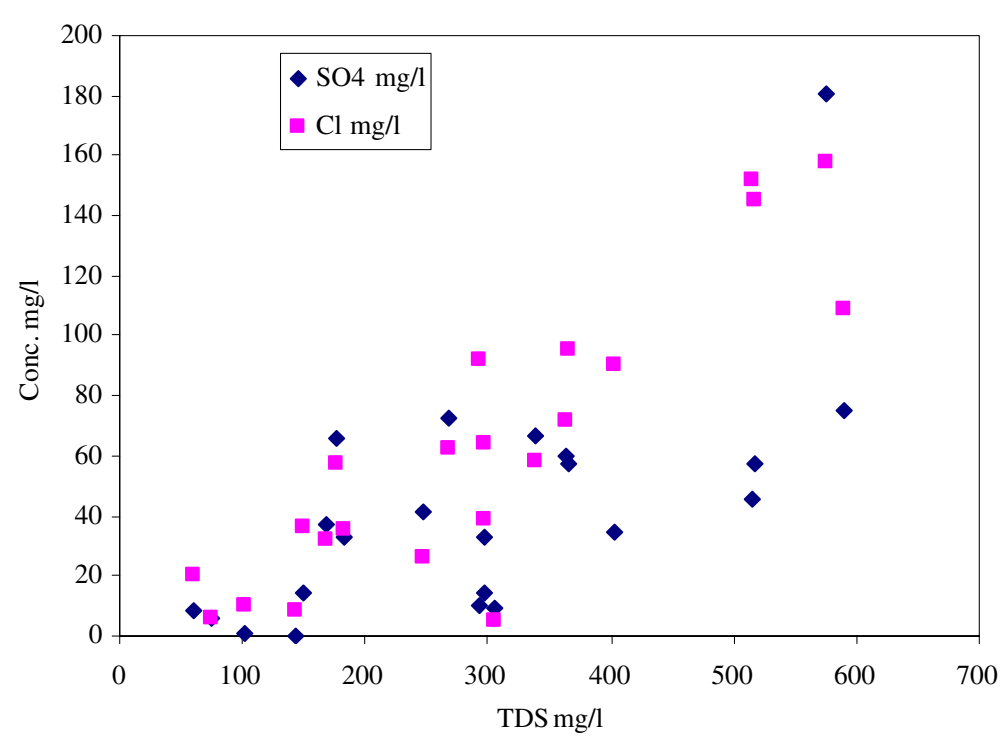

$0.45 \mu \mathrm{m}$ cellulose acetate membrane filters and those for trace metal analysis acidified with $5 \mathrm{ml}$ analytical grade conc. $\mathrm{HNO}_{3}$.

Water samples collected in the field were analyzed in the laboratory for chemical constituents such as $\mathrm{SO}_{4}{ }^{2-}, \mathrm{NO}_{3}{ }^{-}-\mathrm{N}, \mathrm{Cl}^{-}, \mathrm{HCO}_{3}{ }^{-}, \mathrm{Ca}, \mathrm{Mg}, \mathrm{Na}$, and $\mathrm{K}$, both classical and automated instrumental methods as described in the standard methods for analysis of water and waste water (Standard Methods 1998 and EPA 1983). All reagents used were of analytical grade and instruments pre-calibrated appropriately prior to measurement. Replicate analyses were carried out for each determination to ascertain reproducibility and quality assurance.
Fig. 5 Trilinear piper plot of chemical composition of groundwater samples

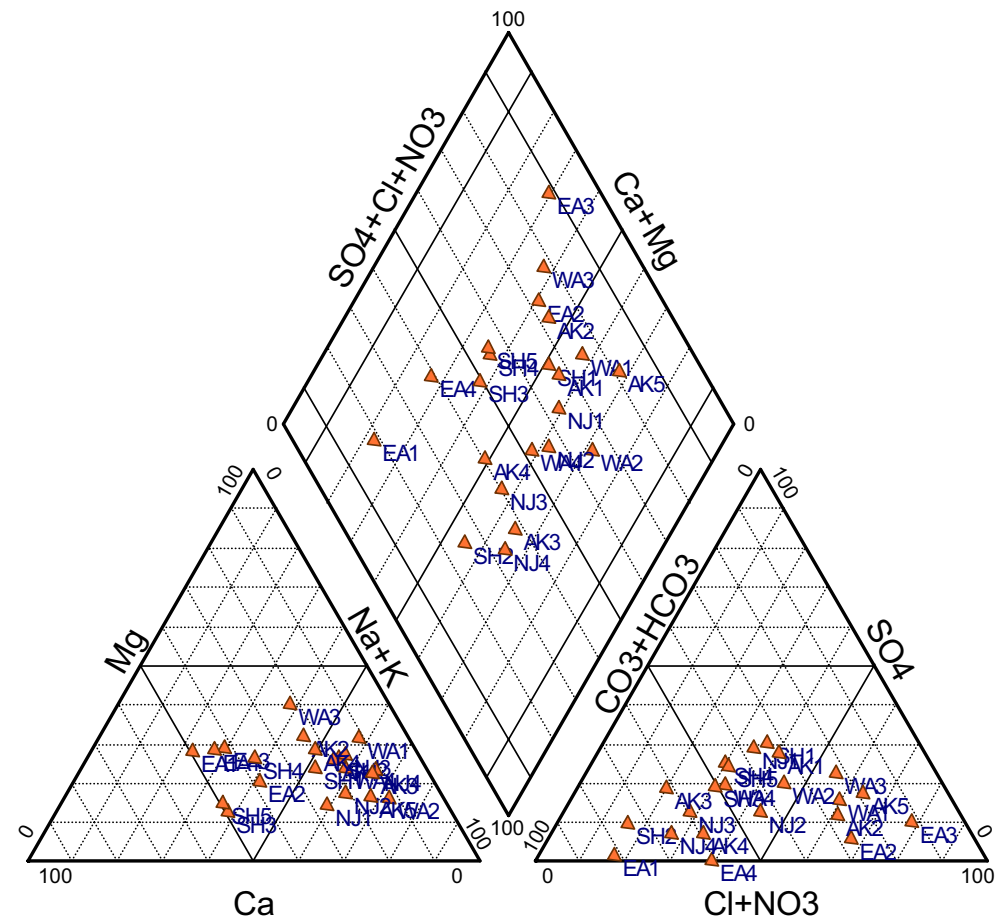


Fig. 6 Correlation of index of saturation of halite and calcite with $\mathrm{Na}^{+}+\mathrm{Cl}^{-}$, and $\mathrm{Ca}^{2+}+\mathrm{HCO}_{3}$

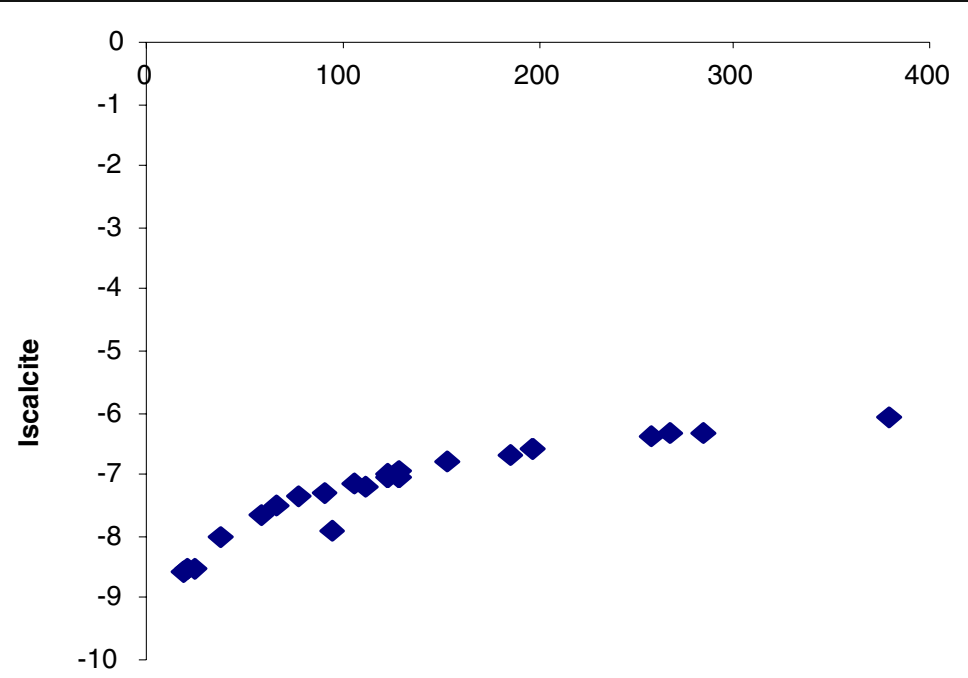

$\mathrm{Na}+\mathrm{Cl}$

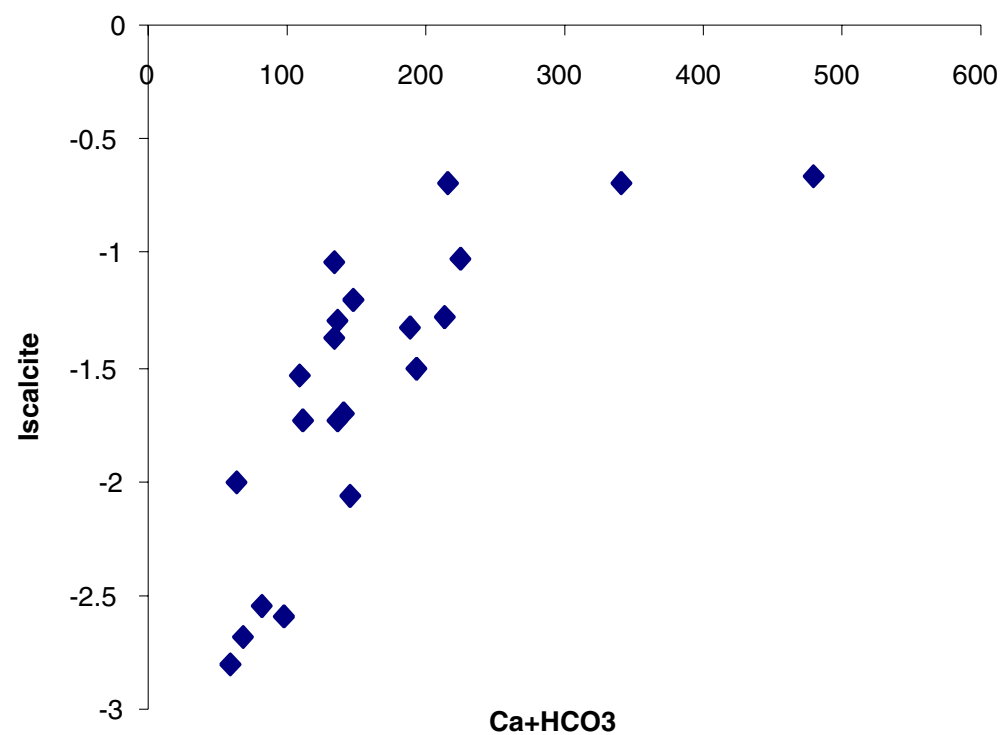

\section{Discussion}

The hydrochemistry of groundwater with electrical conductivity between 107 to $1,053 \mu \mathrm{S} / \mathrm{cm}$ and $\mathrm{pH}$ values between 4.9 and 6.95 is characteristic for the sampled groundwater. It matched favourable with hydrochemical characteristics documented by Water Resources Commission for the Densu River Basin, (CSIR-WRI 2005). AK5 in the Akwapim district recorded the least $\mathrm{pH}$ of 4.49 . In this area of intensive agricultural cultivation, relatively high concentrations of nitrate were measured. Ten locations measured nitrate levels above the limit of $10 \mathrm{mg} / \mathrm{l}$ recommended for drinking water, (WHO 1996), (Table 1 and Fig 2). All these locations fall in the forest zone where there are intensive agricultural activities and population density. The elevated levels can therefore be attributed to the use of chemical fertilizers and sewage. More intensive agricultural production, the ploughing up of grass in a ley-arable rotation, the spreading of animal manure, sewage sludge and effluent can all contribute to nitrate leaching. The prime characteristics of nitrate leaching is that it occurs due to what can be called "untimely nitrate" i.e., nitrate which is in the soil at a 
Fig. 7 Scattergram of the ionic ratio $(\mathrm{Ca}+\mathrm{Mg}) / \mathrm{Na}$ as a function of $\mathrm{HCO}_{3}$ concentration

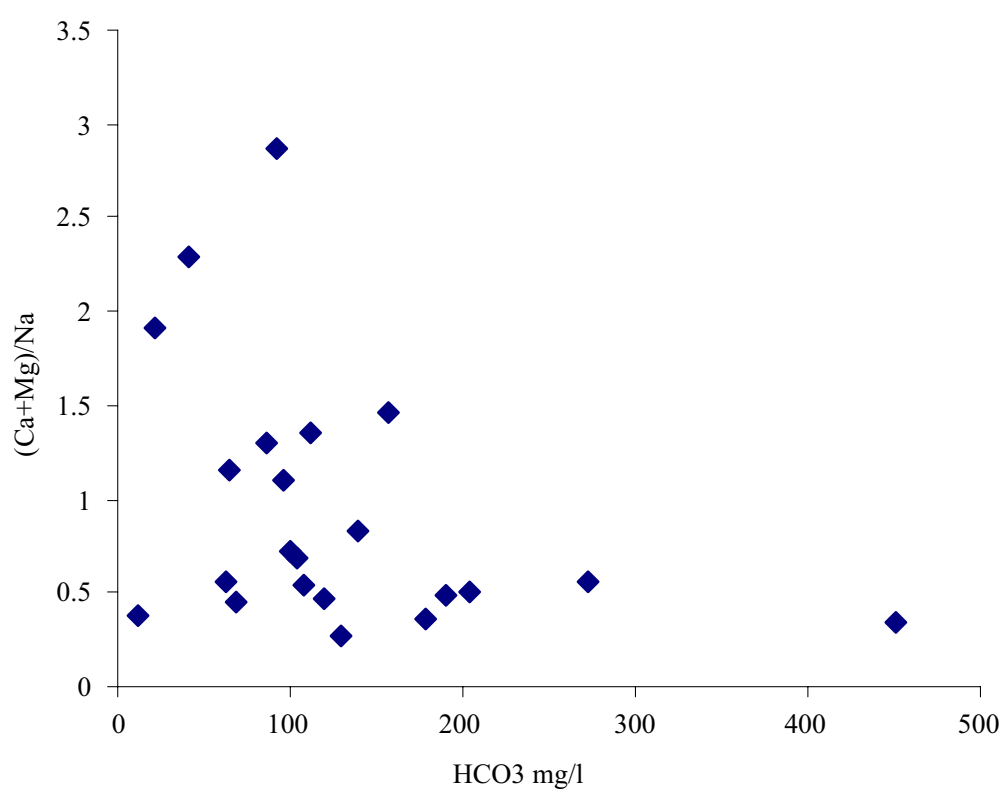

time when a crop cannot use all that is available hence some are leached (Calvet 1990). Heavy precipitation and denitrification rate influences the nitrate content in leached water. The sulphate in the water $(0.03$ and $181 \mathrm{mg} / \mathrm{l}$ ) originates from agricultural activities since it is no where near the high concentration of 275$585 \mathrm{mg} / 1$ normally attributed to dissolution of evaporates (Verhagen et al. 1995). Fears have been expressed that nitrate contaminated water supplies carries the risk of methaemoglobinaemia (blue-baby syndrome) and stomach cancer. The main pollution risk for the aquifers is vertical infiltration of precipitation and flushing of pollutants from the soil.

Results from the study indicate that majority of the samples are fresh water since the Total Dissolved Solids (TDS) did not exceed 500 mg/l (Kattan 1995). Four exceptions were reported for borehole numbers WA1, WA3, AK1 and AK2. Their TDS content varies between 515 and $589 \mathrm{mg} / \mathrm{l}$. The ionic sequence in the groundwater samples were $\mathrm{Na}>\mathrm{Ca}>\mathrm{Mg}>\mathrm{K}$ and $\mathrm{HCO}_{3}{ }^{-}>\mathrm{Cl}^{-}>\mathrm{SO}_{4}{ }^{2-}>\mathrm{NO}_{3}{ }^{-}$(Fig. 3). Permissible levels were exceeded for conductivity in four stations, AK1 $(1,029 \mu \mathrm{S} / \mathrm{cm})$, AK2 $(920 \mu \mathrm{S} / \mathrm{cm})$, WA1 $(922 \mu \mathrm{S} / \mathrm{cm})$ and WA3 $(1,053 \mu \mathrm{S} / \mathrm{cm})$. The ground waters are weakly mineralised and are dominated by $\mathrm{Ca}-\mathrm{HCO}_{3}{ }^{-}, \mathrm{Na}-\mathrm{Cl}$ and mixed $\mathrm{Na}-\mathrm{Ca}-\mathrm{HCO}_{3}{ }^{-}$types of water (Fig 4). Both $\mathrm{SO}_{4}{ }^{2-}$ and $\mathrm{Cl}^{-}$show strong, near positive correlations with total dissolved solids (TDS) or electrical conductivity; Fig 5, which indicates that these conservative constituents of groundwater are being steadily enriched up to high overall mineralization. These facts again suggest very little solute loss through drainage, and that lateral movement of groundwater is minimal (Verhagen et al 1995). The $\mathrm{Na} / \mathrm{Cl}$ ratio with a weighted ratio of 2.01 suggests some reaction with silicate minerals cation exchange releasing $\mathrm{Na}$ at the expense of some other cation. The $\mathrm{Mg} / \mathrm{Ca}$ ratio is maintained between $0.1-0.83$ over most of the aquifer which is consistent with an equilibrium control although the weighted ratio 0.69 is slightly lower than that expected (0.8) if both calcite and dolomite are the controls (Edmunds 2003).

The quality of groundwater depends on the mineralogy, reactivity of drift materials and the degree of equilibrium that has been attained between water and rock, (Robin 2002). The hydrochemical equilibrium conditions controlling the groundwater were therefore studied with the program WATEQ F. The saturation index (SI) of groundwater samples with respect to mineral precipitation is expressed by: S.I.= $\log \left(\mathrm{IAP} / K_{\mathrm{sp}}\right)$ where IAP is ion activity of the solution; $K_{\mathrm{sp}}$ is equilibrium constant of the reaction considered at temperature $T$. The majority of ground waters in the study area are moderately mineralized. The saturation indices indicate that the ground waters in the study area are under saturated with respect to 
calcite, gypsum and halite (Fig. 6). Calcium concentrations are controlled by dissolution of calcite, gypsum and dolomite.

Alkalinity values ranged from 12 to $275 \mathrm{mg} / \mathrm{l}$. The lowest values are for very low residence time and low mineralization groundwater. The values are plotted against the ratio $(\mathrm{Ca}+\mathrm{Mg}) / \mathrm{Na}$ in Fig. 7. This shows the classical relationship where low alkalinity values are associated with $\mathrm{Ca}$ and $\mathrm{Mg}$. High $\mathrm{HCO}_{3}{ }^{-}$ alkalinity can only exist in the presence of $\mathrm{Na}$ dominance which can develop through cation exchange, calcite precipitation, both of which decreases the $(\mathrm{Ca}+\mathrm{Mg}) / \mathrm{Na}$ ratio, and evapotranspirative enrichment of all ions (Verhagen et al. 1995).

The highest concentrations of $\mathrm{Cl}^{-}$and TDS were found in wells in high residential areas while the highest levels of $\mathrm{Na}, \mathrm{Ca}, \mathrm{SO}_{4}{ }^{2-}$ and $\mathrm{NO}_{3}{ }^{-}$were found in agricultural and high density residential areas. Relatively low concentrations of inorganic constituent were found in wells in undeveloped and low density residential areas.

\section{Conclusion}

The groundwater in the eastern region have special economic significance, representing the country's greatest hydrostructure with freshwater. At the same time in this region there are multiple anthropogenic influences. Anthropogenic disturbances have had and continue to have an impact on the aquatic ecosystem of Ghana. Majority of the groundwater sampled were found to be weakly to moderately mineralized with $\mathrm{Na}^{+}, \mathrm{HCO}_{3}{ }^{-}$and $\mathrm{Cl}^{-}$being the dominant ions. Hydrochemical data indicate that intensive use of land for agricultural and industrial activities has impacted greatly on the groundwater quality of the region. Elevated level of $\mathrm{NO}_{3}{ }^{-} \mathrm{N}$ was recorded in about $50 \%$ of the boreholes sampled.

Acknowledgement The authors would like to express gratitude to the International Atomic Energy Agency for facility provided under Technical Cooperation GHA/8/008.
Open Access This article is distributed under the terms of the Creative Commons Attribution Noncommercial License which permits any noncommercial use, distribution, and reproduction in any medium, provided the original author(s) and source are credited.

\section{Reference}

Amuzu, A. T. (1975). A survey of the water quality of the River Densu. WRRI Technical Report, Accra.

Calvet, R. (Ed) (1990). Nitrates-Agriculture-Water: International Symposium by INRA, Paris.

CSIR-WRI (2005). WRIS-GWD/Densu River Basin Groundwater Monitoring Project. Water Research Institute, Accra.

Dickson, K. B., \& Benneh, G. (1980). A new geography of Ghana. London: Longman.

Edmunds, W. M., Guendouz, A. H., Mamou, A., Moulla, A., Shand, P., \& Zouari, K. (2003). Groundwater evolution in the continental intercalaire aquifer of Southern Algeria and Tunisia: trace element and isotopic indicators. Journal of Applied Geochemistry, 18, 811-813.

EPA (1983). EPA methods of chemical analysis of water and wastewater. EPA/600/4-79/020. USA, 374.3.1-375.4.3.

Water Resources Commission (2003) Groundwater assessment: an element of integrated water resources managementthe case of Densu River Basin. Accra.

Junner, N. R. (1940). Geology of the Gold Coast and Western Togoland with revised geological map. Gold Coast Geological Survey Bulletin, 10, 40 9pl.

Kattan, Z. (1995). Chemical and environmental isotope study of fissured basaltic aquifer systems of the Yarmouk Basin. Proceedings of a Symposium on Isotopes in Water Resources Management. Vol 2, Vienna. p.10.

Robin, N. S. (2002). Groundwater quality in Scotland: Major ion chemistry of the key groundwater bodies. Science of the Total Environment, 294, 48-49.

Standard Methods. (1998). Standard method for the examination of water and wastewater. Washington DC: 20th Ed. American Public Health Association

Tazioli, G. S, Cantori, P. M., Ciancetti, G. F. (1995). Intercomparison of different tracers in the evaluation of groundwater dynamics in heterogeneous porous aquifers. IAEA-SM336/40, Vienna. p. 147.

Verhagen, B. T., Marobela, C., Sawula, G., Kgarebe, B. (1995). Geohydrological and mineralization studies with environmental isotopes in a large Kalahari ranching development. IAEA-SM 366/41, Vienna. pp. 91-95.

WHO (1996). Health criteria and other supporting information. 2nd Ed. Guidelines for drinking water, Vol. 2, Geneva. 